\title{
Oarsmen's Views about the Effects of Training on their Daily Lives. Applying Goffman's Theory in the Rowing Communes.
}

\author{
Konstantinos Koukouris, Gounaropoulos Panagiotis, \\ Veinoglou Nikos
}

Department of Physical Education and Exercise Science in Serres, Aristotle's University of Thessaloniki, Greece

ABSTRACT

KEYWORDS

Research on the social dimension of rowing is underrepresented in the coaching science literature. It is well known in rowing circles that many problems arise from the training process in the rowing communes. The complaints of the oarsmen regarding specific problems during the training process in rowing communes were examined in this study. Fourteen oarsmen from Northern Greece with experience from rowing communes were selected and gave in-depth interviews. The complaints expressed by the oarsmen in interviews include the following: Athletic failure in major international events, as expressed subjectively by the oarsmen, results from fatigue prior to events, the incorrect timing of competitive goals (selection in the national team versus success in the international events) and the lack of meritocracy in the selection of oarsmen for the national team. Oarsmen of the national team neglect their studies and their professional future. During their stay in rowing communes the oarsmen are cut off from their social contacts. All oarsmen agreed that competing for a place in the team is a greater source of stress than the actual competition itself. Oarsmen believe that the presence of Greece in international competitions results from the efforts of athletes rather than those of coaches and administrators.

rowing, communes, training, total institutions.

Research on the effects of training camps on athletes' daily lives, particularly at the elite level of sport, is an important area of study. More research is needed in this area, and especially with sports such as rowing that are underrepresented in the coaching science literature. In this study, the training conditions of oarsmen with their coaches in the rowing communes and their suggestions made for an improvement of the structure of rowing communes will be examined. As is well known by all those involved in rowing, high level oarsmen are selected by federal coaches through trials. After the trials, oarsmen participate in intensive rowing communes where they are judged according to their performance on a continuous basis. The training timetable is particularly rigorous. Overall they train for four hours daily. The Greek Olympic Team trains 20 days every month throughout the whole year. Their salary is 580 euros (Senior A class). Most have settled down as port officers, Navy officers etc. 
whereas the students have to choose between studies and rowing. Only 3-4 rowers amongst 20-25 of the Senior A class team have not settled down into a "job". Ulrich estimated that from as early as 1976 Germans spend 27 hours per week (including transportation) on training. Also Tamasne estimated that since $197864 \%$ of Hungarian top oarsmen believe that top training and work are incompatible or that that they could be combined very little.

A definition is needed before we proceed. "A commune is typically a secular institution in which members, through their collective labour and common ownership of property, live together in accordance with a common ideology" (The Penguin dictionary of sociology 1984). In other words commune "refers to either a group of people sharing life and work, a utopian community in which members attempt to found a new social order, based on a vision of an ideal society" (The Concise Oxford Dictionary of Sociology 1994). Instead of a political ideology, in rowing communes we have the sporting ideology of maximum achievement. The rowing commune is a self-actualizing commune which offers the oarsmen the opportunity to realize their full potential as individuals within the context of the communal group.

Rowing communes last between one and two weeks from January until summer, whereas from summer until the championship there is a final commune lasting one to two months. Before the Olympic Games or World Championship rowing communes last much longer. Before the Sydney Olympic Games Greek elite oarsmen used to stay in communes for 20 days every month, returning to their homes for 10 days and back again. This lasted nine months. Considering that in Greece there are only a few full -time oarsmen, whereas the majority are either students or employees, the question arises of how the athletes manage to juggle both their studies and their work. How is their social life affected as a result of their long absence from home? Is "working" in Fire Brigades, Port authorities etc. good enough for people who are trained as P.E. teachers, scientists etc? The effects of rowing communes' training will be studied in this paper.

There is very little free time after training. Only Sunday evenings are left free. Under these circumstances the role of the coach as time manager has become essential (Dick 1986, p. 5). In a performance-oriented society the athlete's progress is the main target. However, according to Treadwell (1986) the Olympic ideals of citius, altius, fortius should not be achieved through training which introduces obedience, compliance, dependence and conventionality with the dominant values. Under this daily timetable the social support of the athlete becomes essential (Rees and Hardy 2000).

The element of play has been undermined in modern contemporary sport (Huizinga 1950, Dunning and Sheard 1979). Subsequently, the world of sport has become very similar to the working mode in work environments (Rigauer 1969, Sheard 1982). In advanced Western societies top athletes are given every material help in order to achieve maximum performance because they represent whole cities, nations etc. According to Tsang (2000) athletic discipline aims to homogenize the individuals and produce top athletes with a united identity. Any diversification in the identity of a young athlete must be wiped out. As an athlete develops, there is a continuous urge towards conventionality and acceptance of the dominant values (Tsang 2000). Obeying the rules of coaches and administrators is regarded as a virtue.

Some coaches are indifferent to their athletes' personal needs inside and outside the club, unable to see their athletes from an holistic perspective (Koukouris 1989). Brettscchneider (1999) estimates that athletes scarcely have two or three hours of free time per day, to be used not only for leisure activities but also for homework. Krane, Greenleaf and Snow (1997) have shown how destructive the athletic environment could be when it is ego-oriented not task-oriented. 


\section{The mechanisms of power}

Rosenberg (1980) identified the management's view of the athlete as a machine which depreciates over time, as a likely source of "personal disorganization". In sport there is constant surveillance and manipulation. But as Johns and Johns (2000, p. 232) concluded, "athletes are willing to settle for a power structure as long as they can find reasons to accept and internalize explanations that justify such an arrangement". The mechanisms of power are complex. As Pitter (1990, p. 319) concluded, the members' acceptance of the legitimacy of a club's structure is aided by a shared belief in the sanctity of the performance principle. Those who hold power within clubs have to assess accurately what combination of coercion and persuasion to use. Potential opposition is incorporated by the hegemonic class through negotiation, concessions, threats and pressures before opposition can reach serious proportions, which would bring its legitimacy into question. Power relations are determined by the kind of objectives agents pursue and by the strategies they employ to achieve them (Hargreaves 1986). Administrators, coaches and athletes are linked through solidarity, they usually have a common ethnic identity and they may have ties of personal affection. That makes the line of authority quite complex. Very often the selection is not based on meritocratic criteria but on private interests and social pressures by significant other people. Decisions over major sport issues are often taken after complex and protracted negotiations among competing interest groups (Lesjo 2000). Tomlinson (1998) maintains that a decisive factor in social events is the "thirst for power" and not only financial interests, as conservative or Marxist economists would argue. Is this obvious in the case of rowing coaches and administrators? Duquin (1984) characterized the power structure within sport as "benevolent dictatorship" by the coaches and sport administrators.

King (1997) supports the idea that social relations between dominant and subordinate groups consist of simultaneous actions of compliance, obedience and resistance. As King points out, the subordinate group is either aware of its position and resists or is deceived and accepts it.

\section{Similarities between rowing communes and totalitarian institutions.}

Staying in the rowing communes for such a long time under such harsh living conditions draws attention to the possible similarity of rowing communes to totalitarian institutions. The similarities between the two can be explored using Goffman's theory about institutionalization and the symbolic management of living conditions within a total institution. Goffman (1961, p. 11) defines a total institution as a place of residence and work where a large number of like-situated individuals, cut off from the wider society for an appreciable period of time, together lead an endorsed, formally administered life. Prison serves as a clear example, providing we appreciate that what is prison-like is found in institutions "whose members have broken no laws". Goffman (1961, p. 17) mentions four components of a total institution: 1) "All aspects of life are conducted in the same place and the same single authority. 2) Each phase of the member's daily activity is carried on in the immediate company of a large group of others, all of whom are treated in the same way and are required to do the same thing together. 3) All phases of the day's activities are tightly scheduled, with one activity leading at a prearranged time into the next, the whole sequence of activities being imposed from above by a system of explicit formal rulings and a body of officials. 4) Finally, the various enforced activities are brought together into a single rational play purportedly designed to "fulfil the official aims of the institution". The implications of this statement are perhaps revealing. The athletic experience, instead of being empowering, might end up as disempowering under this regime. All the above-mentioned characteristics are encountered in the rowing communes. After entering a totalitarian institution the inmate forfeits his right to receive invitations or visit others and thus makes a deep break with the past. To some extent the same happens in rowing communes. Even more so, Goffman adds (1961, p. 25), 
"when entrance is voluntary, the recruit has already partially withdrawn from his home world".

The head of federal coaches is very powerful. All oarsmen live a group life and train, sleep, and eat together in rowing communes. The training program is designed around the athletes reaching maximum performance.

\section{Methodology}

The Participants in the study

Rowing was selected because it is a harsh sport and training loads during rowing communes are especially heavy. Also rowing was chosen because of the long-standing experience of one of the researchers as well as the fact that there is dearth of coaching literature on this issue. It is worth mentioning that each year 15 male and female rowers of the Senior A, 30 rowers of the Senior B National team, 15 adolescents and 35 children participate and train in the rowing communes. Fourtyone male adult oarsmen were estimated, by a Federal coach who had participated in rowing communes (17 oarsmen from clubs in Thessaloniki, 15 from Ioannina, 7 from Kastoria and two from Giannitsa).

Fourteen adult oarsmen out of a total of $41(34.1 \%)$ participated in this study. They were selected by snowball methods. Although the "sample" is small the identification of coaches and oarsmen is difficult. The researchers did not travel outside Thessaloniki for financial reasons. All oarsmen have been active top-level amateur athletes in Northern Greece. They had achieved distinctions at World Rowing Championships for adolescent and young athletes but not at the Olympic Games. Five of them had started their careers in other cities and subsequently moved to the capital of Northern Greece, Thessaloniki, for studies. All the oarsmen encountered various coaches during their careers. Since athletes were unwilling to disclose names of coaches we cannot really estimate the number of coaches. We know that all of them were male coaches but we cannot describe their expertise. Eleven oarsmen were P.E. students whereas three were students in other departments. All of them were 20 to 24 years old and single. Oarsmen were selected according to their level of experience in rowing communes. Also only those athletes who could be located within the city were selected. The recognition of their achievements was made by one of the researchers as well as fellow athletes. The sample was representative of the total number of top-level oarsmen in Northern Greece because one out of three was selected. Female rowers were excluded because of the small number that could have been included. The researchers avoided making assumption about female rowers because "there are issues of power and dominance of the male gender in society" (Altheide and Johnson 1998).

Research Methods

The method of analysis is qualitative rather than quantitative. The rowing communes can best be examined through interpretative sociology, especially by applying the phenomenological approach (Whitson 1976). As Puig and Morrell (1996) pointed out, the acquisition of results in research is related to the methodology used. Depth interviewing as a method was chosen because it was the only way to get the insights of athletes about such a delicate issue. There is an interrelationship between theory and practice. The interviews were structured. The questions were open and allowed the former athletes to express their views freely, and to use their extensive experience in rowing. The interviews lasted between one and three hours. All the interviews were recorded and transcribed meticulously over 130 pages. The researcher attempted to fully understand the world of the subject without interrupting his/her train of thought, a factor considered important by Puig and Morrell (1996). The five forms of 'misdescription' (Walker 1985) which may distort the descriptive validity of a research (incompleteness, oversimplification, suppression, exaggeration and ethnocentricity) were avoided. The 
interviews were structured and the questions accrued from the empirical knowledge of the sport as well as the cognate literatures on elite sport, athlete development and sport psychology. The questions were not formed from any international bibliographies (see the interview guide in the appendix). Interviews were held either in the offices of the local P.E. Department or in the offices of a rowing club after the end of a training session. A researcher must respect the interviewees, should be aware of power relationships between himself and the subjects and respect the anonymity of the key informants (Humberstone 1998, Brannen 1991).

Method of analysis

One of the aims of the analysis was to create categories of reasons given by oarsmen regarding their relationships with their coaches. The categorization of data into sentence-forms (Jones, 1985, Eden, Jones and Sims 1983) and the constant comparative method (Glaser and Strauss 1967, Cote and Salmela 1996) were used. The concentration of units of meaning which accrue from "properties" and, in the final analysis, "categories" were used in the main part of the study.

During the codifying process in the first stage of the interview, the researchers worked together and wanted to specify, "What fits with what?" in their effort to work out the data (Robson 1993). During the second stage the researchers applied labels to groups of words, whereas during a third stage the initial labels were schematized into groups enabling the researchers to formulate a small number of issues or plans.

\section{Results}

Most oarsmen spoke negatively about the federal coaches whereas they applauded the club coaches. But why is there such a big difference in their behaviour, since in the past the same club coaches have acted as federal coaches in rowing communes? Oarsmen seem to only know their club coaches well, not their federal coaches. Oarsmen focused their criticism on the wrong setting of competitive goals by coaches, namely, selection for the national team and not success in international events. Many other issues were raised such as the lack of meritocracy in the selection of oarsmen for the national team, the lack of knowledge by the untrained coaches leading to the blind imitation of coaching schedules from abroad, the non-democratic behaviour of coaches, psychological blackmailing, the conflicts and the indifference to the psychological state of oarsmen, etc. Oarsmen are paid (if they are paid at all) with considerable delay. They cannot easily spend the money they get even if they would like to. It is worth mentioning that a gradual improvement in coaches' work regarding the training schedules and the psychological approach of coaches has been noted recently. Modern training programs are now more adapted to the particular needs of each oarsman. "Training has been improved over the last years, coaches try to adapt the programs to the special needs of each athlete" (oarsmen $\mathrm{j}$ ). There is a clear difference between club coaches and federal coaches. The former regard the oarsman in more humane terms whereas the latter tend to ignore the personality of each oarsman. Of course, occasionally oarsmen themselves choose to keep their coaches at a distance.

\section{Effects of rowing communes training on education}

The majority of oarsmen (10 out of 14) were convinced that rowing communes affect their education to a great extent. In other words their studies have suffered because of their intensive training regime. One of the most serious problems is the simultaneous holding of rowing communes and exams periods in June (and less importantly in January). Their dilemma is whether they should sit exams, thereby risking their participation in contests, or participate in rowing communes, skipping 
courses and failing exams. Many coaches insist on the faithful application of the training programme and the survival of the fittest. Most of the oarsmen finally select the training programme, thus failing in many courses. Some others choose not to sacrifice their studies but they are forced to stop participating in the national team.

Apart from the exams, attending courses is another serious problem. Oarsmen cannot exceed the non-attendance limit (which is $30 \%$ ) because of training sessions. In some extreme cases oarsmen have had to leave the rowing communes (Ioannina or Kastoria) in order to attend obligatory courses in the University of Thessaloniki and return back on the same day (about $600 \mathrm{~km}$ ). From a psychological point of view this is a soul-destroying experience, whereas from a financial point of view the cost is unbearable.

On the other hand, a minority of oarsmen were not affected by rowing communes. These oarsmen said that either conditions were favourable (rowing communes during summer vacations, lack of university obligations) or that they had no impact on their studies. It must be mentioned that because of the absence of so many oarsmen the remaining athletes in the crews cannot train together. Apart from himself an oarsman has to think of his crew. The performance of the whole crew is affected if an oarsman leaves the rowing communes.

Considering that nothing is guaranteed an oarsman is under great risk of failing in both. Oarsmen who come from Ioannina or Kastoria are in a better position. The following extracts from interviews are characteristic of the above-mentioned points:

"Only those who can risk everything can continue, because in fact you risk everything when you leave your studies in order to compete somewhere. You might fail in the contest. For example, when I finished competing and returned to Thessaloniki I realized that I owed 15 courses. It is not by chance that out of 15 courses, 13 of them belonged to the spring semester. I failed to sit exams completely" $\left(\alpha^{\prime}\right)$.

"I was forced to leave the city of Kastoria immediately after the training session to travel to Thessaloniki in order to attend a course and get up early the following morning in order to return to Kastoria for the morning session. This is soul-destroying. From Ioannina also I was forced to leave and return the following day for the training session. This might happen several times by bus and once a month by aeroplane $\left(\gamma^{\prime}\right)$.

\section{The effects of rowing communes on work}

A minority of oarsmen (4) worked during their athletic careers. All of them agreed that rowing communes had serious effects on their profession. Two of them worked with their parents. When they were absent from work their parents were burdened with extra workloads while the profit earned was reduced. For those working in business things are even worse. They cannot leave the work and they are forced to quit the national team. Even those athletes who don't work believe that rowing communes and work are incompatible.

"For as long as I have the rowing communes and I am committed to leave work some days during the year I cannot find work. What could I say to an employer? "You know I am leaving for the rowing communes. He will tell me "where are you going? I pay you." Especially if you have work eight hours a day you can't go anywhere ( $\beta$ ').

"Last year I participated in some trials but I couldn't complete them because I had to leave for Thessaloniki on the last day. Certainly, it affects you a great deal. I should have lost my concerts and rehearsals because a rowing communes might last for a whole month. I can perform in four concerts 
per month on the condition that I also participate in rehearsals. Your supervisor insists that you ought to attend the rehearsals. For three years I was in a dilemma to choose between rowing and music and because music offered me a job whereas rowing did not, I chose music." $\left(\lambda^{\prime}\right)$

\section{Effects of rowing communes on the social life of oarsmen}

The vast majority (11 out of 14 ) believe that social life is affected by rowing communes a great deal. By participating in rowing communes oarsmen are cut off from their social life outside sport. They miss their parents. Sometimes they seek to be away from their parents, but that lasts only a few days. Afterwards, they feel nostalgic for their parents and they want to return. Others feel nostalgia for their home city. They said (11) that they lose all their friends outside sport and that they are thinking of what they could have done together. Their friends might not be as tolerant and full of understanding as they would have liked. Full-time involvement in rowing has limited social life to being exclusively within the sporting realm. Having friends only from within the rowing circles is regarded as boring. Since most of the rowing communes take place in Ioannina those who come from this city are certainly in a better position than others. They feel better because they live and train in their city and have contact with their parents occasionally.

On the other hand, a few (3) oarsmen mentioned that rowing communes did not affect their social life. They said that the existence of friends outside the rowing circles helped them. The relatively short duration of rowing communes and their focus on the target helps the athletes to have a good social life.

The results proved that for the vast majority of oarsmen their participation in the rowing communes affects their social life to a great extent. They are usually so exhausted after training that they are not in the mood to visit friends and acquaintances. "Although it may sound odd, in the evening I don't have appetite most of the time because I try to find time for sleep. You are fagged out from training and you can't do otherwise."

Last of all, there is the extreme example of an oarsman who felt insecure when he left the rowing communes. He has become institutionalized because by staying in rowing communes for a such a long time he can't face the world outside. The longer an oarsman spends in rowing communes the more problems he might have to face.

"I didn't want to admit it. I understood that when I was leaving the rowing communes to come back home I was feeling insecurity, because I had serious adjustment problems. In the rowing communes everything is ready for you... you don't have stress for mundane things. They take you under their wings. They all protect you from whatever might happen to you. Although we are tired when we leave, we search for it, we want to return back to where we were" $\left(\alpha^{\prime}\right)$.

On the contrary, another oarsman mentioned that it is very good to isolate oneself in a rowing communes because you can discover yourself away from the family.

\section{The stress of maintaining the correct weight}

Most of the oarsmen in the sample (9 out of 14) compete in the lightweight division. It was found that their efforts to lose weight was another source of stress. Most lightweight oarsmen (6) had to make an effort to lose weight. A few (3) have never encountered any problems in maintaining the ideal weight. They were careful with their diet but never felt under pressure to lose weight. Many oarsmen (5) however suffered serious weight problems. It was difficult for them to lose weight. Many 
times they left the table without having a substantial meal. They felt the hardship of losing weight and this had consequences for their morale and sport performance. The stress becomes larger during contest periods. For example an athlete said that he abstained even from water before contests. Two of the oarsmen were obliged to lose a lot of weight sometime, they were under some pressure and felt such deprivation that they could not try to compete in the lightweight division again. Thus, the results gave the impression that the excessive diets could have a serious psychological effects on oarsmen.

A few oarsmen dropped out of the sport completely in order to recover e.g. one oarsman lost $10 \mathrm{~kg}$ within one and a half months. The trials he went through left him psychologically drained from exercise and he disengaged from rowing for two years. Much of the pressure is due to coaches. All lightweight oarsmen who competed in the heavyweight division felt dissatisfied.

"I felt drained, I wanted to have a rest and I stopped rowing. I had followed a tough diet. I had lost a lot of weight within a very short period of time and that knocked me down. I didn't take part in the trials for the national team. The following year I stopped completely. I felt very sad and I didn't try again. It's not easy to lose $10 \mathrm{~kg}$ within a month and a half."

"I can't stand oppression. When the coach tells me "come here to be weighed. Why are you so heavy? You must lose weight", he makes me feel outraged. I weigh myself at home. I am not bothered by what coaches have to say because they don't understand my psychology. In some cases when the coach asked me why I ate, I stepped on the scales. I was overweight and as a reaction I would go back home and eat much more" ( $\beta$ ').

\section{Do oarsmen feel under pressure during their rowing communes?}

All oarsmen agreed that the main reason for stress is striving for a position in the crew and not the race itself. Oarsmen compete against each other even during training. Often oarsmen train harder than is expected by coaches in order to beat their team-mates during training e.g. the coach might expect 17 strokes per minute but oarsmen might row 24 strokes per minute. Often over-exertion happens during rowing communes. Many athletes (11) believe that coaches are responsible for this stress. Taking part in rowing communes is not enough to become members of the national team. An oarsman has to constantly prove his expertise. The training programme is structured around overstress and doubt. They emphasize constantly to the oarsmen the importance of achieving a certain time for staying in the rowing communes. From the coaches' point of view a qualification time is essential. However, according to athletes the result is even more stress. Delaying the formation of crews and the continuous trials before events upset some oarsmen. Finally, many oarsmen redirect their attention from international success to qualifying instead for the national team. Oarsmen do not have time to work together and as a result they cannot perform well abroad. Even after the formation of crews coaches constantly challenge the oarsmen' abilities. Oarsmen feel that they are forced to achieve maximum performance at the wrong time, namely before and not during an International competition. Many oarsmen's performances deteriorate as a result of stress which is caused by the unrealistic targets set by coaches. The above-mentioned points are illustrated below:

"Coaches put athletes, especially the young, under extreme pressure. When the coach says "if you don't achieve this time you won't go to the games" he cuts my throat. In the meantime they demand some extraordinary targets, the time that I will achieve in the finals. How could I achieve this target while I am exhausted? He creates such stress for a young athlete that the oarsman's time actually deteriorates" (oarsman b). 


\section{Discussion}

Having read the oarsmen's description rowing communes seem to be a new form of totalitarian institution. Is it possible to talk about totalitarianism in sport, which is regarded by most people as a form of "entertainment"? According to Maragopoulou and Tzanetaki (1987, p. 207) "clear forms of totalitarian institutions exist from the past. However characteristics of totalitarian institutions in housing, working, or entertainment appear more often as time passes by".

Obviously, federal coaches have the right to decide about the kind of training, the crews and the selection of athletes for the national team. Rowing communes often coincide with the university exam period. Oarsmen are threatened with losing the chance of participating on National Team if they take their exams at the university or at secondary school. Some have lost their position in the national team. Federal coaches are very critical of oarsmen, but do athletes have a good subjective judgment of their own abilities? Oarsmen strongly believe that they are under constant pressure to achieve maximum performance at the wrong time. The psychological pressure is tremendous. According to oarsmen, another serious mistake is the international delay in choosing the crews and setting trials at the last minute before important intentional championships. This procedure tires out the oarsmen both physically and psychologically. Setting targets at different dates could solve the problem. Oarsmen were relieved and relaxed during International Championships because they had already passed the main obstacle, namely winning a place on the national team.

Results from the data compiled have led us to believe that oarsmen should be informed about the qualification and selection criteria of the coaches. Poor communication means poor management. According to Gilroy (1986, p. 241) "Coaches and selectors might consider trying some of the following: inform all players of the length and nature of the selection process (explaining any chances to this pattern as necessary) supply each athlete with details of the criteria for selection and personally inform those who are unsuccessful before a list is posted. Why not work with athletes to identify the criteria?"

All coaches should have graduated from a Physical Education Department. The training programme should be longstanding, not annual. The loss of talented oarsmen because of coaches' lack of knowledge is unacceptable. Favouritism should be checked. According to interviewees, reaching the highest level of performance should be achieved at the right time. The training programme should not be general but conditioned to each athlete's needs, instead of blindly following training programmes which are tailor-made for other countries. Oarsmen believe that Greek coaches should study the working conditions abroad and the foreign coaches' qualities, and take what is required and then adapt it to their own situation.

As early as 1986 Dick suggested that an Ethics Committee should be established which should supervise the training method. Federal coaches should be assisted by sport scientists, a medical team and dieticians on a permanent basis. Without scientific support, coaches cannot assess an oarsmen's abilities accurately.

Instead of guidance and periodic inspection (as in many employer-employee situations), in total institutions there is surveillance, everyone does what he has been clearly told is required of him. "The basic segregation in total institutions is between the managed people and a small supervisory staff" (Goffman 1961). Inmates live within the institution and have limited contact with the outside world. On the other hand, members of the supervisory staff work on an eight-hour basis and they are incorporated into the broader society. Although there are no fences, rowing athletes leave the commune only a few times a week (usually on Sunday evening and possibly another evening during the week). The consecutive changes of crews and the complete mystery of the final crew for the 
national team is a standard tactic which upsets the oarsmen psychologically. In a similar fashion, oarsmen are paid (if they are paid at all) with considerable delay. They cannot easily spend the money they get even if they would like to. Total institutions are incompatible with a crucial element of our society - the family. As Goffman (1961, p. 22) points out "those who eat and sleep at work, with a group of fellow workers, can hardly sustain a meaningful domestic existence". There are married rowers in the communes, but they are childless. It is practically impossible for a married oarsman with children to remain in the rowing communes.

The autonomy and freedom of action is hindered for young rookies. As Goffman (1961, p. 47) points out "total institutions disrupt or defile precisely those actions that in civil society have the role of attesting to the actor and those in his presence that he has some command over his world, that he is a person with "adult" self determination, autonomy and freedom of action". When autonomy and freedom of action are under threat, then the inmate feels that he is not treated as an adult but as a child. Sometimes oarsmen in the rowing communes have precisely this feeling that they are not treated as adults. The social status of oarsmen in rowing communes is regarded as very low. The social status of oarsmen is low since federal coaches disregard their opinion about various issues. Goffman (1961, p. 63) mentions an important mode of adaptation to the setting of a total institution, which is known as that of "conversion". The inmate appears to take over the official or staff view of himself and tries to act out the role of the perfect inmate. The inmate appears to accept the official line of thought and plays the role of the perfect inmate.

In a similar way in rowing communes, there are ideal ways of behaving which oarsmen try to endorse "for their own sake". Overall, there are striking similarities between rowing communes and total institutions.

As mentioned earlier, some oarsmen had the feeling of not being treated as adults. In the Charter of Human Rights of the European Union, endorsed by all countries in 2000, the human rights of all citizens, including of course the athletes, are guaranteed. Unfortunately, it is not a binding agreement. Of outstanding importance are the United Nations' Human Rights Declaration in 1948 and the European Convention for the Protection of Human Rights, signed in Rome in 1950. According to Korchia (2001): "The centres of athletic excellence where an excessive training regime is imposed on juveniles might fall within the jurisdiction of article 3 about torture prohibition. Moreover, article 4 about slavery and forced labour could be referring to sport because excessive training and the obligation to participate in events and championships is enforced sometimes on athletes".

The young athlete seems to be exploited both by parents and the coaches. A code of sport ethics must be established so that the coaching process can be checked (Maridakis and Psaromati 2001). The top-level athlete becomes a martyr who aspires to success. The most dangerous doping is the psychological one (Dionisatos and Minotakis 2001).

Kidd and Donnelly (2000, p.131) pointed out that "the aspirations for democracy and liberation evoked by the banner of human rights cannot be achieved without human rights in sports; that is, human rights cannot be realized without all sports participants fully enjoying those rights". The enforcement of child labour laws in the domain of rowing is essential in order to minimize "sport labour'. The social pressure for the enforcement of child labour laws in sports will not accrue from within but from outside the existing sport system (Donnelly 1997). According to Durkheim (1964), to avoid professional ethical codes in jobs similar to the professional codes of the medical profession should be developed. 


\section{Reliability of the study}

All interviewees involved in the study received the initial results by mail and made comments. There were two main researchers involved in compiling the data. Pidgeon and Henwood (1997) refer to the following criteria for the assessment of the research quality. Theory should be incorporated well in the various levels of abstraction and generalization. The categories must be the cornerstones of the emerging theory. The researcher is not independent of the subjects studied, but there is an interdependent relationship. The results of good qualitative research should be easily recognizable from the subjects who gave the data. In qualitative research we should consider not the generability but the transferability of the study. According to Sparkes (1998), qualitative research cannot be regarded as just another variation of positivism, and neither could it be judged using the same criteria. There are other reliable and legal ways of learning. According to Altheide and Johnson (1988) the validity of the results is shown from the following points: the researcher should describe the phenomenon not only from his own point of view but also from other perspectives (validity as culture). Also a male researcher should avoid making assumptions about the second gender (validity as relativity). The production of knowledge should be useful to those involved in the study (Altheide and Johnson 1998). One of the shortcomings of the study is the limited application to theory or practice outside of the particular context in which the data were collected.

\section{Conclusions}

Results from the interviews conducted pointed to the fact that there is a fundamental lack of understanding for the coaches on the part of the oarsmen. Oarsmen's studies have suffered because of their intensive training regime. One of the most serious problems is the simultaneous holding of rowing communes and exams periods in June. By participating in rowing communes oarsmen are cut off from their social life outside sport. Lightweight oarsmen's efforts to lose weight was another source of stress. They felt the hardship of losing weight had consequences for their morale and sport performance. The stress becomes larger during contest periods. The results gave the impression that the excessive diets could have serious psychological effects on oarsmen. Exhausting and systematic training could lead to the neglect of studies and absence from lessons and exams, long and difficult journeys to attend courses, isolation from friends, isolation from the other sex, austere diet (for lightweight oarsmen). It might lead to excessive competition, even during training sessions, and lack of psychological support to compete against foreign athletes. If exhausting and systematic training takes place in poor living conditions, in cold and dirty dormitories, there is a fear of injuries which hinders performance and leads to disappointment. Furthermore, excessive competition even during training sessions and a lack of psychological support to compete against foreign athletes might result in overtraining and incorrect training targets. Inability to improve performance might eventually lead to having second thoughts about their athletic careers. Austere diet might lead to psychological saturation, absence from training communes and eventually to disengagement. All the abovementioned points are illustrated in the following cognitive map (see figure 1). Oarsmen did make suggestions for improving the situation. 


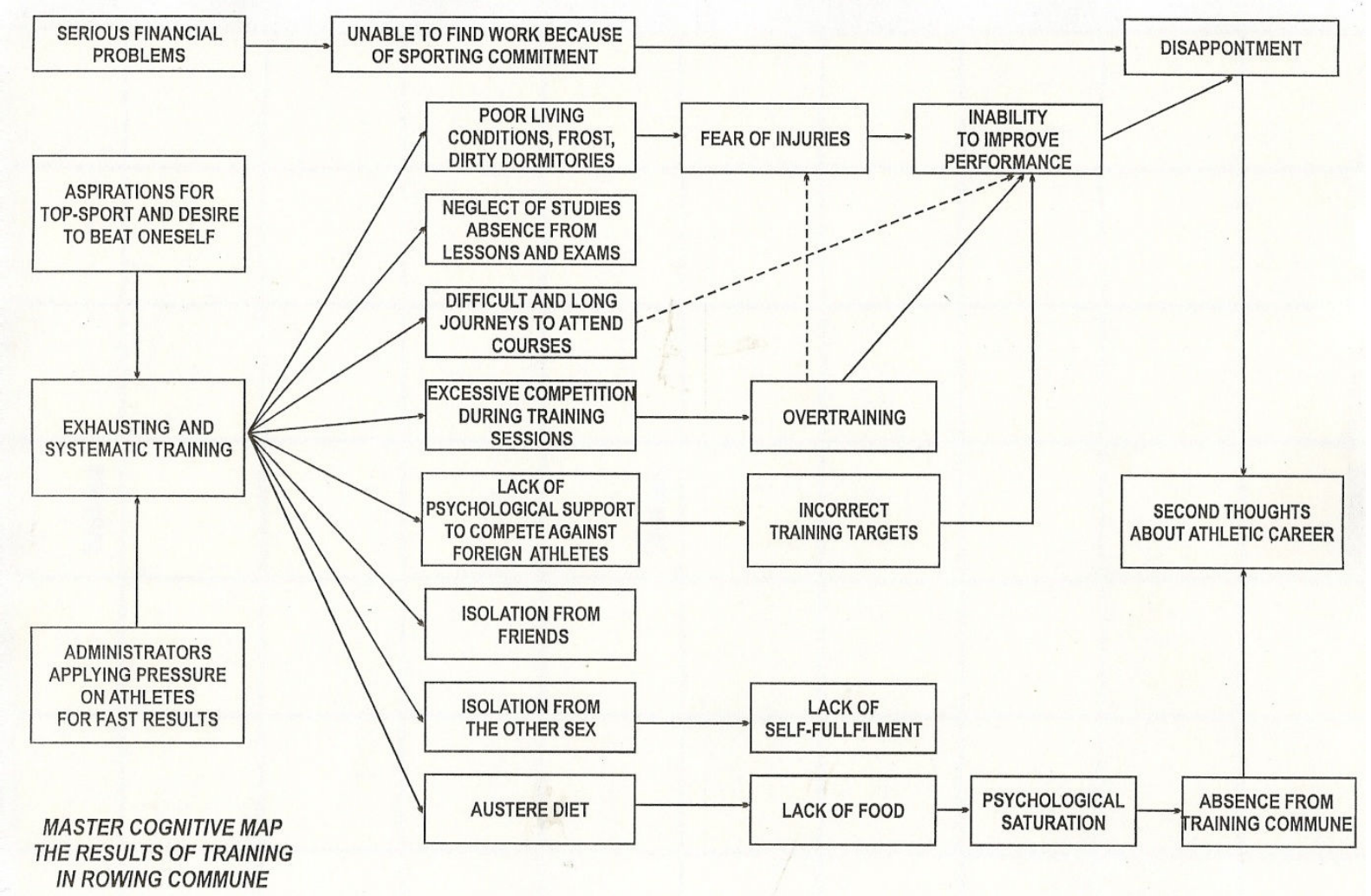

Figure 1. Master cognitive map. The results of training in rowing commune.

Oarsmen strongly believe that they are under constant pressure to achieve maximum performance at the wrong time.

\section{REFERENCES}

Altheide, D., Johnson, J. (1998). Criteria for Assessing Interpretative Validity in Qualitative Research. In Denzin, N. and Lincoln, Y. (Eds.). Collecting and Interpreting Qualitative Materials. Sage Publications.

Brannen J. (1998). The study of sensitive subjects.

Brettschneider, W. D. (1999). "Risks and opportunities: Adolescents in top - level sport - Growing up with the pressures of school and training. European Physical Education Review, 5, 2, 121-133.

Cote, J., Salmela, J. (1996). The organizational tasks of high performance gymnastic coaches. The Sport Psychologist, 10, 261-277.

Dick, F. (1986). Coaching the way ahead. Coaching Focus. Published by the National Coaching Foundation, Spring 1986.

Donnelly, P. (1997). Child Labour, Sport Labour: Applying Child Labour Laws to sport. International Review for the Sociology of Sport, 32, 4, 389-406.

Durkheim, E. (1964). The division of labour in society. New York, USA: Free Press.

Duquin, M. (1994). Power and authority: Moral consensus and conformity in sport. International Review for the Sociology of Sport, 19, 3-4.

Dunning, E., Sheard, K. (1979). The figurational dynamics of modern sport: Notes on the sociogenesis of achievement striving and the social significance of sport. Sportwissenschaft, 9, 4. Also in Dunning and Elias (Eds.) Sport and free time in the evolution of civilization (Greek edition, Dromeas, Athens Published in 1998). 
Dionisatos and Minotakis (2001). Unethical aid in improving the sport results. Speech during the $2^{\text {nd }}$ Panhellenic Cogress of Sports Law, Athens.

Eden, C., Jones, S., Sims, D. (1983). Messing about in problems. U.K.: Pergamon Press.

Hargreaves, J. (1982). Sport and Hegemony: Some theoretical problems. In Cantelon, H. and Gruneau, R. (Eds.) Sport, culture and the modern state. Canada: University of Toronto Press.

Hargreaves, J. (1986). Sport, power and culture. U.K.: Polity Press. Cambridge.

Henwood, K., Pidgeon, N. (1992). Qualitative research and psychological theorizing. British Journal of Psychology, 83, 97-11.

Huizinga, J. ( 1950). Homo Ludens: A study of the play element in culture. Bosto: Beacon Press.

Humberstone, B. (1998). Recreation and connections in and with nature: Synthesizing ecological and feminist discourses and praxis? International Review for the Sociolgy of Sport, 33, 4, 381-392.

Gilroy, S. (1986). Selection in sport. How to cope. Coach Education. Preparation for a profession. Proceedings of the VIII Commonwealth and International Conference on Sport, Physical Education, Dance, Recreation and Health, Glasgow 1986. E. and F. N. Spon, London and New York.

Glaser, B., Strauss, A. (1967). The discovery of grounded theory: Strategies for qualitative research. New York, USA: Aldine de Gruyter.

Goffman (1961). Asylums. London and New York: Penguin Books.

Jones, S. (1985b). The analysis of depth interviews. In R. Walker (Ed.) Applied Qualitative Research. England.

Johns, D., Johns, J. (2000) Surveillance, subjectivism and technologies of power: An analysis of the discursive practice of high - performance sport. International Review for the Sociology of Sport, 35, 2, 219-234.

Kidd, B., Donnelly, P. (2000). Human Rights in Sports. International Review for the Sociology of Sport, 35, 2 , 131-148.

King, A (1997). The lads: Masculinity and the new consumption of football. Sociology, 31, 2, 329-346.

Korchia, N. (2001). Human Rights and sport. Speech during the $2^{\text {nd }}$ Panhellenic Congress of Sports Law. Athens.

Koukouris, K. (1989). The disengagement of elite Greek athletes from organized, competitive sport. Unpublished Ph.D. dissertation. U.K.: University of Manchester.

Krane, Greenlaf and Snow (1997). Reaching for gold and the price of glory: A motivational case study of an elite gymnast. The Sport Psychologist, 11, 53-71.

Lesjo, J. H. (2000). Lillehammer 1994. Planning, figurations and the «Green» Winter Games. International Review for the Sociology of Sport, 35, 3, 282-293.

Maragopoulou, A. and Tzanetakis, X. (1987). Objects and space in totatitarian institutions. The Greek Review of Social Research, 67, 206-213.

Maridakis, S., Psaromati, E. (2001). Scientific research in International Sports Law Association about sport ethics. Speech during the $2^{\text {nd }}$ Panhellenic Cogress of Sports Law. Athens.

Pidgeon, N. and Henwood, K. (1997). Using grounded theory in psychological research. In Hayes (Ed.) Doing qualitative analysis in psychology (pp. 245-273). Hove, East Sussex, U.K.: Psychology Press.

Pitter, R. (1990). Power and Control in an Amateur Sport Organization. International Review for the Sociology of Sport, 25, 4, 309-322.

Puig, Morrell (1996). Relating the method: Use of the itinerary concept in analysis of sport biographies. International review for the sociology of sport, 31,4, 439-454.

Rees, T., Hardy, L. (2000). An investigation of the social support experiences of high-level sports performers. The sport psychologist, 4, 4, 327-347.

Rigauer, B. (1981). Sport and work. Translated by Allen Guttmann. New York, USA: Columbia University Press.

Robson, C. (1993). Real World Research. A resource for social scientists and practioner- researchers. (see especially chapter 12: The analysis of qualitative data). Oxford UK and Cambridge USA: Blackwell. 
Rosenberg, E. (1980). Gerontological theory and athletic retirement . In S. Greendorfer \& A. Yiannakis (Eds.) Sociology of Sport : Perspectives, First Annual NASS Conference proceedings. West Point, NY: Leisure Press.

Sheard, K. G. (1982). Rigauer: Sport and work. (Book review), Sociological Review, 30, 2, 309-311.

Sparkes, A. (1998). Validity in qualitative inquiry and the problem of criteria: Implications for Sport Psychology. The Sport Psychologist, 12, 363-386.

Tamasne, Foldesi (1978). Study of favoured sociological and sociopsychological factors influencing performance of athletic teams in rowing. International Review of Sport Sociology, 13, 17-32.

Tomlinson, A. (1998). Domination, negotiation and resistance in sport cultures. Journal of sport and social issues, 22, 3, 235-240.

Treadwell, P. (1986). How do we begin to move towards a profession? Coaching Focus. Published by the National Coaching Foundation.

Tsang. T. (2000). Let me tell you a story: a narrative exploration of identify in high performance sport. Sociology of sport Journal, 17, 44-59.

Ulrich, H. (1976). The social structure of high level sport. International Review of Sport Sociology, 2, 11, 139149.

Walker, R. (1985). An Introduction to Applied Qualitative Research. In Walker (Ed.) Applied Qualitative Research. Ebgland: Gower, Aldershot.

Whitson, D. (1976). Method in sport sociology. The potential of a phenomenological contribution. International review for the sociology of sport, 4, 11, 53-68.

\section{INTERVIEW GUIDE}

1) How old are you?

2) When did you start participating in rowing?

3) What was your best achievement in rowing events up to now?

4) When did you participate in a rowing commune for first time?

5) How often do they invite you to rowing communes of the national team?

6) Could you describe a typical day in a rowing commune? How many hours do you train per day? How much free time do you have? How do you spend your free time?

7) Do you believe that your participation in the rowing communes influences your other activities (your studies, your school, your work etc) Have you ever made some sacrificies on your formal education during your athletic career?

8) Do you believe that your participation in the rowing communes influences your social life or not?

9) Have you ever felt any loneliness during your stay in the rowing communes or not?

10) Have you ever felt any pressure or stress because of excessive training, competing for a place in the crew or competing for a gold medal?

11) (For lightweight oarsmen only) Do you make systematic efforts to lose weight or not? Are you motivated by the coach on this issue? Do you have a food deprivation feeling?

12) What sort of relations do you have with your teammates in the rowing communes?

13) How is your relationship with the coaches and how do they treat the athletes generally? Are they right or wrong when they choose athletes or when they design the training programme? Do you think that they have the required qualifications as national coaches for the job? 